\title{
Pelatihan dan Pendampingan bagi Peningkatan Kapasitas Aparat dan Institusi Desa dalam Perencanaan dan Implementasi Pembangunan
}

\author{
Setiadi $^{1,2}$, Henny Ekawati ${ }^{2}$, Fadlan Habib ${ }^{2}$ \\ ${ }^{1}$ Departemen Antropologi, Fakultas Ilmu Budaya, Universitas Gadjah Mada \\ ${ }^{2}$ Peneliti di Pusat Studi Kependudukan dan Kebijakan, Universitas Gadjah Mada \\ Korespondensi: setiadi_antro@ugm.ac.id
}

\begin{abstract}
The implementation of Law No. 62014 faces obstacles due to the weak quality of village officials and institutions. This has an impact on the weakening role of the village government in its function as a development accelerator. It is necessary to increase the capacity of the apparatus in order to understand how development planning processes should be carried out at the village level, and how these processes are supported by strong village government institutions. In addition, there needs to be a control mechanism for the village government. This can be done by strengthening the role of the $B P D$. With the increased quality and capacity of village government apparatus and institutions, as well as strong civil society control played by the BPD, there will be a synergy in implementing good development at the village level. Village officials are no longer the sole player in village development. Efforts to create these ideal conditions continue to be in progress at the village level and will always be dynamic due to the influence of supralocal powers which are sometimes not in line with the development and will of the local community.
\end{abstract}

Keywords: apparatus quality; development planning; civil society; village development

\begin{abstract}
Abstrak
Implementasi UU No. 6 Tahun 2014 menghadapi kendala akibat lemahnya kualitas aparat dan kelembagaan desa. Hal ini berdampak pada semakin lemahnya peran pemerintah desa dalam fungsinya sebagai akselerator pembangunan. Perlu adanya peningkatan kapasitas aparat agar memahami bagaimana proses-proses perencanaan pembangunan harus dilakukan di tingkat desa serta bagaimana proses-proses tersebut didukung oleh kuatnya kelembagaan pemerintah desa. Selain itu, perlu ada mekanisme kontrol terhadap pemerintah desa. Hal ini bisa dilakukan dengan penguatan peran BPD. Dengan meningkatnya kualitas dan kapasitas aparat dan kelembagaan pemerintah desa serta kontrol masyarakat sipil yang kuat yang diperankan oleh BPD, akan ada sinergi pelaksanaan pembangunan yang baik di tingkat desa. Aparat desa tidak lagi menjadi pemain tunggal pembangunan desa. Upaya penciptaan kondisi ideal ini terus berproses di tingkat desa dan akan selalu dinamis akibat pengaruh kekuasaan supralokal yang terkadang tidak sejalan dengan perkembangan dan kehendak masyarakat lokal.
\end{abstract}

Kata kunci: kualitas aparat; perencanaan pembangunan; masyarakat sipil; pembangunan desa 


\section{Pendahuluan}

Otonomi desa yang telah bergaung sejak tahun 1970-an (Phahlevy, 2016) mendapatkan momentum kembali sejak lahirnya UU No. 6 Tahun 2014. Eksistensi melalui undangundang ini menjadi peluang bagi desa untuk lebih maju, mandiri, dan demokratis. Tujuan ini akan tercapai apabila kualitas individual aparat desa mampu menerapkan prinsip pemerintahan yang baik dan mendudukkan partisipasi masyarakat secara inklusif dalam proses-proses pengambilan keputusan bagi kepentingan bersama (Agustina, 2019). Kuat dan responsifnya pemerintah desa sangat dibutuhkan untuk mewujudkan tujuan-tujuan adanya kewenangan desa. Kewenangan tersebut menjadikan desa dalam pengambilan keputusan tidak lagi menunggu persetujuan dari otoritas pemerintahan yang lebih tinggi (Antlöv, 2003).

Undang-Undang No. 6 Tahun 2014 tentang Desa (UU Desa) menjadikan desa memiliki hak dan kewajiban atas aset dan sumber daya yang dimilikinya. Melalui kewenangan berdasarkan asas rekognisi dan subsidiaritas yang dimiliki tersebut, desa akan lebih mampu mengapitalisasi sumber dayanya untuk menghadirkan kesejahteraan bagi masyarakat. Proses pembangunan yang ada di desa sudah sepatutnya melibatkan seluruh kepentingan yang ada di desa secara partisipatif. Proses pembangunan yang dari, oleh, dan untuk masyarakat harus dijadikan sebagai dasar pijakan dalam perumusan pembangunan desa.

Cerita tentang kuatnya ikatan sosial dan modal sosial yang dimiliki oleh masyarakat desa harus tetap menjadi landasan dalam pembangunan desa. Infrastruktur sosial tersebut harus menjadi penopang dalam keseluruhan pembangunan desa. UU Desa pada dasarnya sebagai peneguh dari tradisi berdesa tersebut. Besarnya kewenangan desa yang termanifestasi dalam hak dan kewajiban desa harus ditempatkan untuk memperkuat jalinan sosial masyarakat sebagai kesatuan masyarakat hukum. Hak yang dimiliki oleh desa adalah 1)mengatur dan mengurus kepentingan masyarakat berdasarkan hak asalusul, adat istiadat, dan nilai-nilai sosial budaya masyarakat; 2)memilih kepala desa serta menetapkan BPD dan perangkat desa lainnya; 3)mengelola kelembagaan desa; dan 4) mendapatkan sumber-sumber pendapatan desa. Selain hak, desa juga memiliki beberapa kewajiban, yaitu 1) melindungi masyarakat, menjaga persatuan, kesatuan dan kerukunan nasional serta keutuhan Negara Kesatuan Republik Indonesia; 2)meningkatkan kualitas kehidupan masyarakat; 3)mengembangkan kehidupan demokrasi; 4)mengembangkan pemberdayaan masyarakat; dan 5)meningkatkan pelayanan dasar masyarakat. Hal ini memungkinkan desa-desa untuk kembali ke sistem adat (Vel dan Bedner, 2015).

Berdasarkan uraian tersebut, menjadi jelas bahwa materi yang diatur di dalam UU Desa cukup banyak, tetapi yang paling krusial adalah tentang penataan desa, kewenangan desa, penyelenggaraan pemerintahan desa, peraturan desa, keuangan desa, dan aset desa. Dari kesemuanya itu, salah satu isu yang paling sensitif tetapi dirindukan oleh banyak orang, baik aparat desa maupun masyarakat desa, adalah adanya dana desa. Besarnya dana yang dikelola oleh desa menyisakan tanda tanya besar bagi banyak kalangan, apakah aparatur desa mampu untuk mengelola dana tersebut secara baik dan transparan? atau justru menyebabkan mereka terjerembab pada masalah yang berimplikasi pada hukum. Sebagai contoh, tidak sedikit aparat desa yang gagal mengelola dana dengan dengan baik dan akhirnya bermasalah secara hukum. Ibarat mata uang, UU ini juga menghasilkan 
sisi gelap tata-pemerintahan sehingga semakin menjauhkan arah perkembangan desa dan gagal menghasilkan banyak desa mandiri.

Isu KKN (Korupsi, Kolusi, dan Nepotisme) menjadi isu paling kuat dan banyak menjerat aparat desa. KKN menjadi istilah yang umum dan didukung dengan pemberitaan yang masif di media massa. Kewenangan dan dana besar yang ada di desa berubah menjadi bencana karena banyak hal yang bertentangan dengan hukum dilakukan oleh aparat desa. Banyak tipe korupsi yang muncul di desa, yang intinya adanya penyalahgunaan berbagai sarana dan prasarana, termasuk anggaran, publik untuk kepentingan dan keuntungan pribadi (Woodhouse, 2002). Tidak mengherankan apabila kemudian banyak ditemui bahwa dalam konteks reformasi tata pemerintahan desa. Kewenangan desa semakin ditingkatkan dan digelontor dengan dana desa yang jumlahnya tidak sedikit dan dana desa pun membawa korban. Kasus korupsi di pemerintahan desa mewarnai berbagai pemberitaan media (Syahidah, 2018).

Kegiatan penguatan kapasitas kelembagaan dan aparatur desa yang dikemas dalam kegiatan pelatihan dan pendampingan ini berangkat dari keprihatinan dan semangat untuk pemberdayaan masyarakat desa agar siap dalam melaksanakan otonomi desa. Observasi menemukan bahwa berbagai tantangan yang dihadapi aparat desa setelah diberlakukannya UU desa, antara lain, yakni pentingnya penguatan pemerintahan desa agar muncul tata kelola yang lebih baik. Beberapa kelemahan yang ditemukan dalam praktik tata pemerintahan desa adalah belum terbangunnya sistem check and balances di lembaga-lembaga desa, khususnya antara pemerintah desa dan elemen masyarakat sipil yang diwakili oleh BPD. Belum terbangunnya sistem tersebut disebabkan oleh kuatnya dominasi kepala desa dalam menjalankan roda pemerintah desa sehingga fungsi dari Badan Permusyawaratan Desa (BPD) sebagai lembaga legislator di desa, yang salah satu fungsinya adalah melakukan pengawasan terhadap jalannya pemerintah desa, belum terasa. Faktor utama yang menyebabkan kondisi ini adalah rendahnya SDM yang dimiliki oleh BPD karena selama ini, program penguatan kapasitas pemerintahan yang ada di desa, baik yang berasal dari pemerintah daerah maupun lembaga-lembaga yang lain, hanya pada penguatan di pemerintah desa, sedangkan BPD masih kurang tersentuh.

Implikasi yang paling dirasakan dari kurang terbangunnya sistem check and balances adalah munculnya peluang korupsi yang masif di desa, yang disebabkan oleh pengelolaan anggaran, yang justru secara sistematis memberikan peluang untuk pemanfaatan anggaran untuk kegiatan nonpembangunan. Adanya kelompok-kelompok penekan di desa merupakan masalah lain yang semakin merepotkan tata kelola keuangan di perdesaan. Untuk menghilangkan berbagai potensi penyimpangan, hal utama yang harus dilakukan adalah penguatan keterlibatan lembaga desa dan masyarakat sehingga bisa ditumbuhkan semangat mengawal proses tata kelola pemerintahan desa menuju "good village gavernance". Tujuan penataan desa yang baik ini adalah terciptanya akuntabilitas keuangan desa dari yang sebelumnya hanya pada tataran akuntabilitas administratif menuju akuntabilitas secara substantif.

Sebagai upaya berkontribusi dalam penciptaan desa dengan tata kelola pemerintahan yang baik, tim Pendampingan Desa dari Pusat Studi Kependudukan dan Kebijakan Universitas Gadjah Mada (PSKK-UGM), atas dukungan pendanaan sebuah perusahaan Migas, melakukan kegiatan pelatihan dan pendampingan di beberapa desa di Jawa Timur, khususnya terkait dengan sistem tata kelola keuangan desa dan peningkatan 
peran lembaga desa lainnya seperti BPD untuk lebih berperan aktif dalam fungsi kontrol terhadap pemerintah desa. Kegiatan yang dilakukan oleh PSKK-UGM diwujudkan dalam bentuk pelatihan dan pendampingan secara rutin terhadap aparat desa dan institusinya.

Tujuan dilaksanakannya program peningkatan kapasitas aparat dan institusi desa ini adalah (a)meningkatkan kapasitas pemerintah desa dalam mengimplementasikan Rencana Pembangunan Jangka Menengah Desa (RPJMDes) dan Rencana Kegiatan Pembangunan Desa (RKPDes); (b)penguatan kapasitas pemerintah desa dalam mengelola anggaran desa (perencanaan, pengelolaan administrasi/pelaporan); serta (c)menguatkan peran lembaga desa yang lain seperti Badan Perwakilan Desa (BPD) dalam menjalankan Tugas Pokok dan Fungsi (TUPOKSI).

Untuk mencapai tujuan-tujuan tersebut, dilakukan serangkaian kegiatan pelatihan dan pendampingan. Kegiatan pelatihan dan pendampingan terdiri atas dua tema, yaitu tata kelola keuangan desa dan peningkatan kapasitas BPD.

Dari rencana program yang sudah disusun ini, diharapkan pemahaman dan kemampuan perangkat desa dan BPD akan mengalami peningkatan. Selain itu, perangkat desa dan BPD juga diharapkan mengimplementasikan materi pelatihan dan pendampingan tersebut dalam menjalankan tupoksinya masing-masing.

\section{Pendekatan Pelaksanaan Program}

Program pendampingan dan pelatihan dilakukan di dua desa di Kecamatan Gandu, yaitu Desa Gandu dan Desa Madurejo. Dasar pemilihan kedua lokasi tersebut adalah kedua desa tersebut memiliki sumber penerimaan yang berasal dari Alokasi Dana Desa (ADD) terbesar di Kabupaten Bojonegoro.

Melalui serangkaian assessment awal, diputuskan bahwa materi pelatihan dan pendampingan disesuaikan dengan kebutuhan dan keinginan dari aparat desa yang bersangkutan. Kebutuhan dan keinginan digali melalui kegiatan assessment yang dilakukan sebelum implementasi program sehingga desain program benar-benar sesuai dengan kebutuhan masyarakat setempat. Kegiatan assessment tersebut bertujuan untuk menjaring dan menggali informasi terkait dengan kebutuhan dan keinginan aparat desa, yang berkaitan pula dengan implementasi UU Desa yang baru. Hasil assesment tersebut digunakan sebagai landasan dan acuan dalam penyusunan program. Pada Program Peningkatan Kapasitas Aparat dan Institusi Desa dalam Perencanaan dan Implementasi Pembangunan ini, PSKK UGM menitikberatkan pada dua tema. Masing-masing tema terdiri atas dua kegiatan, yaitu pelatihan dan pendampingan. Seluruh kegiatan tersebut dilaksanakan dalam kurun waktu selama 7 bulan, yakni antara Oktober 2016 sampai dengan April 2017.

Ada dua kegiatan utama yang dilaksanakan, yakni sebagai berikut.

1. Pelatihan dan Pendampingan Tata Kelola Keuangan Desa. Pelatihan dan pendampingan tata kelola keuangan desa bertujuan untuk memberikan pemahaman kepada perangkat desa terkait dengan alur dan proses penganggaran yang ada di desa mulai dari perencanaan, pengganggaran, pelaporan, dan pertanggungjawaban. Kegiatan ini dilakukan secara rutin selama 4 bulan mulai dari Oktober 2016 sampai dengan Januari 2017. Indikator keberhasilan kegiatan ini adalah sebagai berikut. 
- kemampuan aparat (PTPKD) untuk melakukan penatausahaan anggaran;

- munculnya pelibatan masyarakat dalam mekanisme perencanaan dan penganggaran pada saat penyusunan RAPBDes;

- pemahaman aparat mengenai prinsip-prinsip pengelolaan anggaran.

- pelatihan dan pendampingan peningkatan kapasitas BPD.

2. Pelatihan dan pendampingan Tupoksi BPD. Secara spesifik, kegiatan ini bertujuan meningkatkan peran kontrol lembaga pemerintahan desa lainnya guna terciptanya sistem check and balances. Dengan materi ini, diharapkan BPD mampu melakukan pembenahan secara internal dan mampu melakukan fungsinya sebagaimana yang diamanatkan dalam implementasi UU Desa. Kegiatan ini dilaksanakan selama 3 bulan mulai dari Februari-April 2017. Indikator keberhasilan kegiatan ini adalah sebagai berikut.

- Terselenggarakannya satu kali pelatihan Tupoksi BPD.

- BPD dapat memahami dan menjalankan fungsinya secara lebih optimal.

- Dalam menjalankan tugasnya, BPD sudah sesuai dengan tata tertib yang sudah ada.

- Adanya program kerja yang jelas dari BPD sehingga ada capaian tolok ukur kinerja dari BPD.

\section{Pelaksanaan Program}

Program Peningkatan Kapasitas Aparat dan Institusi Desa dalam Perencanaan dan Implementasi Pembangunan ini merupakan program kegiatan pada tahun kedua yang diselenggarakan oleh tim PSKK UGM. Desain kegiatan yang sudah direncanakan untuk pekerjaan kali ini hanya dua tema, yaitu (1) tata kelola keuangan desa dan (2) peningkatan kapasitas BPD. Tujuan kegiatan pertama adalah terciptanya tata kelola keuangan desa yang baik berdasarkan asas-asas good governance dalam pengelolaan keuangan desa (transparan, akuntabel, partisipatif serta dilakukan dengan tertib dan disiplin anggaran). Sementara itu, tujuan kegiatan kedua adalah adanya keberimbangan kekuasaan yang ada di desa sehingga check and balances akan terjadi di desa.

\section{Tata Kelola Keuangan Desa}

Salah satu kebijakan dari lahirnya undang-undang desa tahun 2014 adalah terkait dengan adanya sumber dana yang besar yang masuk ke desa. Keberadaan sumber dana yang besar tersebut merupakan tantangan bagi pemerintahan desa beserta segenap stakeholders untuk bisa mengolah sumber dana dan peluang yang besar yang ada di desa karena tidak secara otomatis dengan dana yang besar akan langsung terwujud kesejahteraan apabila tidak mampu mengelola secara baik. Agar terwujud pembangunan desa yang efektif dan efisien tentunya dibutuhkan perencanaan yang matang dengan memperhitungkan segenap potensi yang dimiliki, tim kerja yang peofesional, pola pelaksanaan pembangunan yang tepat, pengawasan yang mampu menghindari kebocoran dan penyimpangan, serta adanya sistem pelaporan dan evaluasi yang transparan serta akuntabel. Apabila lima hal tersebut tidak bisa diwujudkan, potensi sumber dana dan kewenangan yang besar tersebut akan menjadi sia-sia, bahkan menjadi bencana. Untuk mewujudkan semua ini dibutuhkan sumber daya manusia, terutama perangkat desa yang profesional dari segi pendidikan, 
pengetahuan, dan keterampilan sesuai tugas yang diembannya.

Tantangan utama yang ada di Desa Gandu dan Desa Madurejo dalam mewujudkan pemerintahan desa yang ideal dapat disebabkan oleh dua hal. Pertama adalah faktor internal yang ada di dalam pemerintahan desa, yakni minimnya SDM perangkat desa yang mumpuni, baik secara kualitas maupun secara kuantitas. Keterbatasan inilah yang menyebabkan akselerasi pembangunan yang ada di desa dengan penyelenggaraan pemerintahan desa tidak bisa berjalan maksimal. Besarnya dana yang harus dikelola oleh pemerintah desa memiliki risiko yang cukup tinggi dalam pengelolaannya, khususnya bagi aparatur pemerintah desa. Fenomena

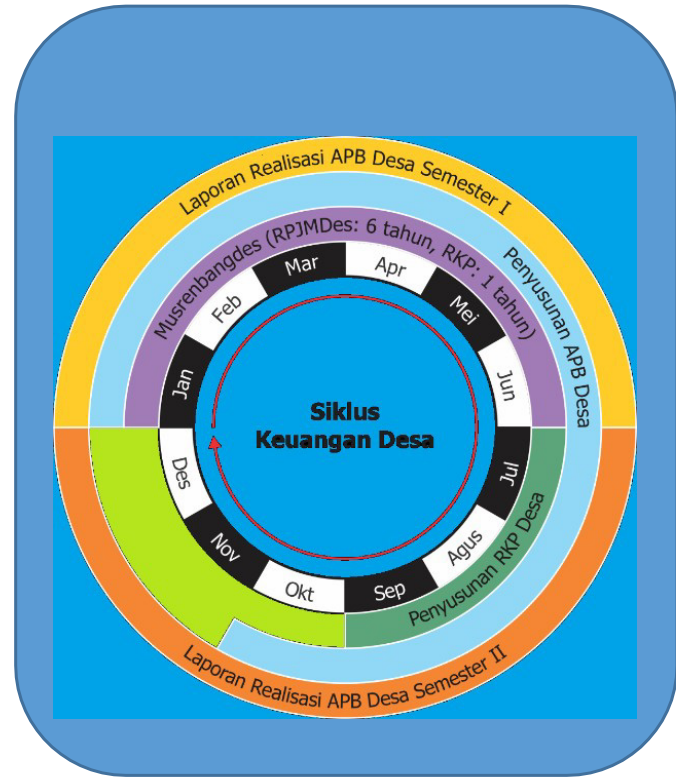

Gambar 1. Diagram Kalender/Siklus Tata Kelola Keuangan Desa pejabat daerah yang tersangkut kasus hukum jangan sampai terulang kembali dalam skala pemerintahan desa. Aparatur pemerintah desa dan masyarakat desa yang direpresentasikan oleh BPD harus memiliki pemahaman atas peraturan perundang-undangan dan ketentuan lainnya serta memiliki kemampuan untuk melaksanakan pencatatan, pelaporan, dan pertanggungjawaban.

Selain faktor SDM, faktor kepemimpinan kepala desa juga menjadi penentu keberhasilan yang ada di desa. Dominasi yang sangat kuat oleh kepala desa sering menimbulkan permasalahan tersendiri. Arah pembangunan desa yang seharusnya sudah tertata melalui dokumen RPJM Desa tidak bisa dijalankan dengan baik hanya karena kepala desa bisa dengan mudah memutuskan program berdasarkan keinginan pribadinya. Tantangan yang lain adalah kekompakan antarperangkat desa. Faktor kokompakan antarperangkat desa penting terwujud karena di situlah awal tertatanya manajemen pemerintahan desa. Selain itu, eksistensi Lembaga Kemasyarakatan Desa (LKD) kurang berfungsi sebagaimana mestinya. Karang taruna, PKK, dan LKMD hanya sebatas memiliki kepengurusan, tetapi kontribusinya di masyarakat tidak tampak.

Berdasarkan tantangan tersebut, PSKK UGM melakukan serangkaian kegiatan yang bertujuan menjembatani antara realitas yang ada dan tujuan besar yang akan diperoleh, yaitu meningkatnya kualitas SDM aparatur pemerintahan desa yang profesional. Pendekatan yang digunakan dalam mengimplementasikan kegiatan pelatihan dan pendampingan tata kelola keuangan desa yang diselenggarakan mulai Oktober 2016 sampai dengan Januari 2017 didasarkan pada kalender/siklus tata kelola keuangan desa. Acuan tersebut dijadikan sebagai pijakan agar terjadi sinkronisasi antara kegiatan yang dilakukan aparat desa dan program kegiatan pelatihan serta pendampingan sehingga lebih applicable.

Kegiatan penguatan tata kelola keuangan desa selama 4 bulan itu memiliki aktivitas kegiatan dan capaian: (a)pendampingan penyusunan dokumen Perubahan Anggaran Pendapatan dan Belanja Desa (PAPBDes) tahun 2016; (b)pendampingan penyusunan 
laporan pertanggungjawaban keuangan desa yang berupa laporan realisasi pelaksanaan APBDes 2016 dan LKPJ kepala desa tahun 2016; (c)pendampingan perencanaan anggaran desa yang berupa penyusunan Rencana Kerja Pembangunan (RKP) tahun 2017; (d) pendampingan dalam proses penganggaran desa yang berupa penyusunan Rencana Anggaran Pendapatan dan Belanja Desa Tahun 2017 (RAPBDes 2017).

Kegiatan pendampingan tata kelola keuangan desa diawali dengan melakukan pendampingan penyusunan dokumen Perubahan Anggaran Pendapatan dan Belanja Desa (PAPBDes) tahun 2016. Perubahan anggaran ini terjadi karena adanya salah proyeksi perhitungan yang dilakukan oleh pihak kabupaten terkait dengan capaian dana bagi hasil migas. Dampak dari adanya salah proyeksi perhitungan ini adalah Desa Gandu dan Desa Madurejo harus mengembalikan uang ke rekening kas desa sekitar 450 juta rupiah.

Selain adanya pengurangan pendapatan desa tersebut, faktor yang menyebabkan adanya perubahan anggaran adalah adanya pergeseran anggaran dan program. Pergeseran ini muncul paling banyak di Desa Gandu yang disebabkan oleh sikap kepala desa yang tidak taat pada dokumen perencanaan yang sudah dibuat sebelumnya. Kesan yang muncul pada saat penyusunan perencanaan dan penganggaran di awal adalah sekadar kebutuhan administratif dan rutinitas belaka sebagai prasyarat penurunan anggaran. Padahal, seharusnya, kepala desa sebagai kuasa pengguna anggaran harus taat atas perencanaan yang sudah dibuat,

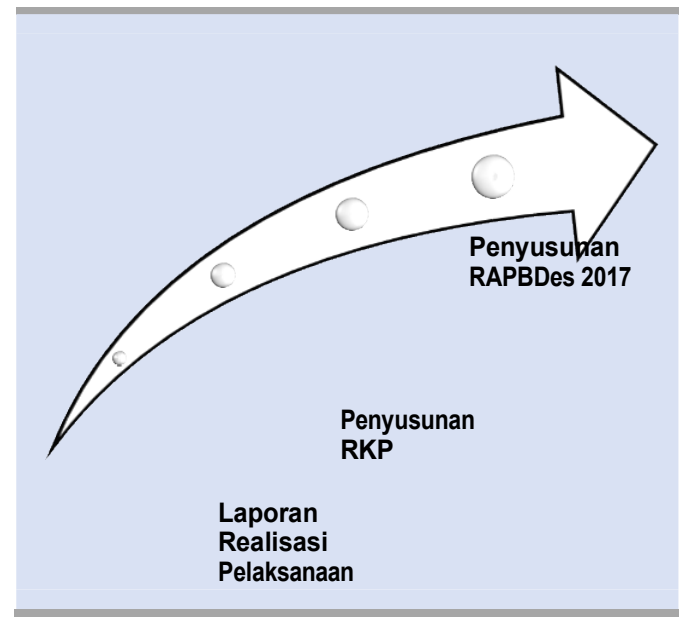

Gambar 2. Tiga Aspek Penting Pelatihan dan Pendampingan yang memiliki kekuatan hukum.

Upaya yang dilakukan adalah memberikan pemahaman kepada perangkat desa untuk taat pada ketentuan yang ada, terutama kepala desa. Kepala desa selaku kuasa pengguna anggaran memiliki kewenangan untuk menetapkan kebijakan pelaksanaan anggaran serta penetapan tim pengelola keuangan desa-Pelaksana Teknis Pengelola Keuangan Desa (PTPKD) - yang terdiri atas sekretaris desa sebagai koordinator PTPKD, kaur sebagai pelaksana teknis, dan bendahara desa sebagai bendaharawan yang bertugas menerima, menyimpan, menyetorkan/membayar, menatausahakan, dan mempertanggungjawabkan penerimaan pendapatan desa serta pengeluaran pendapatan desa dalam rangka pelaksanaan APBDes. Oleh karena itu, tugas kepala desa tidak lagi seperti bendaharawan desa. Tugas kepala desa sesuai dengan ketentuan yang ada, yakni hanya sebagai pihak yang menyetujui pengeluaran yang telah ditetapkan dalam APBDes dan melakukan tindakan yang mengakibatkan pengeluaran atas beban APBDes.

Pemberian pemahaman sekaligus pembentukan PTPKD ini ternyata cukup efektif dalam mengontrol munculnya banyak perubahan kebijakan anggaran oleh kepala desa. Hal ini karena setiap kaur sebagai pelaksana teknis kegiatan sudah dari awal mengetahui program yang menjadi tanggung jawabnya, baik secara pelaksanaan kegiatan maupun pelaporan keuangannya. 
Kegiatan yang mendapatkan pendampingan dari kegiatan tata kelola keuangan desa adalah pendampingan dalam penyusunan laporan pertanggungjawaban realisasi pelaksanaan APBDes 2016. Kegiatan ini lebih pada pendampingan dalam penyusunan dokumen perdesnya. Kendala yang dihadapi dalam penyusunan dokumen perdes ini adalah waktu pelaksanaan kegiatan pembangunan yang melampaui batas periode keuangan. Seharusnya, Januari 2017 sudah tidak ada lagi kegiatan pembangunan atau program kegiatan yang dibiayai oleh anggaran 2016, tetapi terpaksa harus dikerjakan karena turunnya anggaran yang masuk ke rekening kas desa tahap akhir pada bulan Desember. Ketidaksesuaian inilah yang selalu muncul setiap tahunnya di Kabupaten Bojonegoro.

Pada era keterbukaan seperti saat ini, sistem pengelolaan keuangan desa harus berjalan berdasarkan asas-asas transparansi akuntabilitas, partisipatif, serta dilakukan dengan tertib dan disiplin anggaran. Pengelolaan keuangan desa yang dimaksud tentunya adalah pengelolaan satu tahun anggaran, yakni yang dimulai sejak 1 Januari hingga 31 Desember.

Upaya yang dilakukan dalam memecahkan masalah tersebut adalah dengan mengusulkan skema pelaksanaan program yang periodisasi kegiatannya lebih jelas. Kegiatan dikemas dalam bentuk evaluasi pelaksanaan kegiatan. Diskusi dan evaluasi pengelolaan keuangan desa tersebut bertujuan untuk mendorong lahirnya komitmen dari perangkat desa, kususnya kepala desa dan bendahara desa serta perangkat lain, untuk membenahi jadwal pengelolaan kegiatan desa/penyelenggaraan pemerintahan desa, baik pembangunan maupun bidang lain yang terprogram dengan lebih baik lagi agar program kegiatan terutama infrastruktur tidak dilakukan pada akhir tahun anggaran.

Selain kegiatan tersebut, pendampingan juga menyasar upaya peningkatan sumbersumber Pendapatan Asli Desa (PADes), terutama yang bersumber dari hasil sewa Tanah Kas Desa (TKD). PADes bersumber dari TKD yang setiap tahunnya tidak ada peningkatan. Hal ini untuk menambah kontribusi yang masuk ke desa, terutama yang bersumber dari tanah bengkok. Sebagian perangkat ada keengganan jika tanah bengkok akan dilelang secara terbuka karena mereka masih beranggapan bahwa itu merupakan bagian dari gaji/insentif mereka. Padahal, dengan adanya regulasi yang baru yang menyatakan bahwasanya perangkat desa berhak menerima penghasilan tetap dan tunjangan, seharusnya tanah bengkok sudah sepenuhnya menjadi kewenangan desa. Untuk itu, sedikit demi sedikit, pendampingan juga dilakukan guna memberikan penjelasan kepada perangkat desa untuk berkenan melepaskan tanah bengkoknya untuk dikelola oleh desa agar memberikan nilai yang besar bagi pendapatan asli desa.

Ketentuan yang mengatur mekanisme pemberian penghasilan tetap dan tunjangan kepada perangkat desa di Kabupaten Bojonegoro diatur dalam Perbup Nomor 35 Tahun 2015 tentang Penghasilan Kepala Desa dan Perangkat Desa, yang dalam Pasal 6 peraturan tersebut dijelaskan terkait dengan pemberian tambahan tunjangan dari hasil pengelolaan tanah bengkok. Seharusnya, dengan terbitnya peraturan tersebut, perangkat desa bisa dengan mudah melepaskan tanah bengkoknya untuk dimanfaatkan dengan nilai ekonomis yang lebih tinggi. Namun, upaya ini sedikit terkendala karena tanah bengkok merupakan perlambangan kekuasaan dari perangkat desa.

Keberhasilan pendampingan dalam kaitannya dengan meningkatkan PADes dari pengelolaan tanah TKD ada di Desa Gandu. Hasil Sewa Tanah Kas Desa yang awalnya 


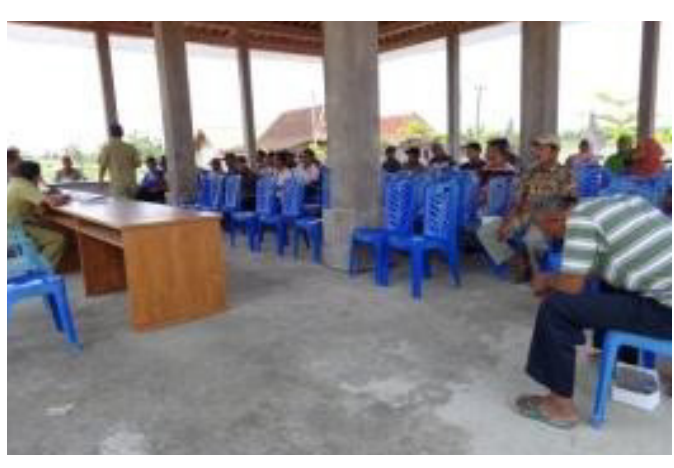

Gambar 3. Pendampingan Musdes

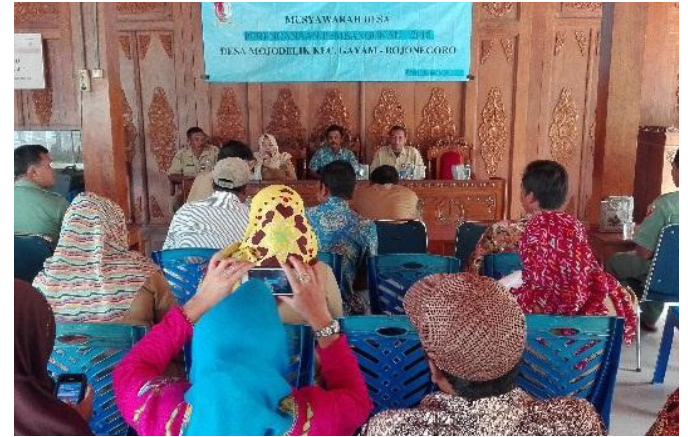

Gambar 4. Persiapan Pelatihan Tata Kelola Keuangan Desa

Rp52.990.800,00 mengalami peningkatan pada tahun 2017 menjadi Rp72.213.000,00. Peningkatan ini terjadi karena sistem yang digunakan adalah lelang terbuka. Itupun sebagian tanah yang akan dikelola oleh karang taruna diberikan harga yang relatif kecil guna membantu operasional kegiatan karang taruna.

Kegiatan berikutnya yang masuk dalam tata kelola keuangan desa adalah pendampingan dalam penyusunan RKP desa tahun 2017. RKP Desa merupakan penjabaran dari RPJM Desa untuk jangka waktu satu tahun. RKP Desa memuat rencana penyelenggaraan pemerintahan desa, pelaksanaan pembangunan, pembinaan kemasyarakatan, dan pemberdayaan masyarakat desa. RKP Desa berisi evaluasi pelaksanaan RKP Desa tahun sebelumnya, prioritas program, kegiatan, dan anggaran desa yang dikelola oleh desa maupun melalui kerja sama antara desa/pihak ketiga dan kewenangan penugasan dari tingkatan pemerintah yang lebih tinggi. RKP Desa menjadi dasar penetapan APB Desa.

Dokumen yang disiapkan dalam membuat perencanaan dalam RKP Desa adalah dokumen Rencana Pembangunan Jangka Menengah (RPJM) Desa. Musyawarah desa (Musdes) pada saat pelaksanaan penyusunan RKP Desa dilakukan secara partisipatif pada forum musyawarah aktif dalam perencanaan pembangunan desa, yang melibatkan lembaga desa, lembaga kemasyarakatan desa, dan unsur masyarakat. Pelibatan banyak unsur ini diharapkan akan lebih banyak mengakomodasi seluruh usulan pembangunan dari bawah. Pelaksanaan musdes tentang perencanaan pembangunan (RKP Desa) mengikuti jadwal yang sudah dibuat oleh pihak kabupaten sehingga forum Musdes perencanaan pembangunan cukup dilakukan satu kali saja. Namun, pembahasan dan mekanisme penjaringan masalah sudah dilakukan oleh Tim Penyelenggara Musrenbang (TPM) beberapa minggu sebelumnya. Capaian kegiatan ini adalah tersusunnya dokumen perencanaan pembangunan berupa RKP tahun 2017 untuk kedua desa dampingan. Proses penyusunan dokumen sudah sangat partisipatif karena pelibatan semua stakeholders yang ada di desa.

Kegiatan pendampingan yang terakhir pada tema tata kelola keuangan desa adalah penyusunan RAPBDes desa. Kegiatan ini juga menjadi satu rangkaian dalam perencanaan pembangunan. Proses penganggaran yang ada di desa sering kali terkendala pada teknis perhitungan berdasarkan ketentuan yang ada dan juga tidak adanya harga satuan barang/jasa. Kendala tersebut sering kali memberikan peluang terjadinya praktik- 
praktik penyelewengan anggaran. Untuk itu, yang dilakukan oleh pendamping adalah pelibatan BPD dalam proses persetujuan Perdes RAPBDes untuk mencermati nilai dari masing-masing kegiatan, apakah bernilai layak atau tidak sebagaimana fungsi BPD, yakni sebagai fungsi budgeting.

Pelibatan BPD di sini bukan hanya pelibatan secara administrasi, melainkan juga secara substansi. Maksudnya, pelibatan BPD yang pada awalnya hanya membubuhkan tanda tangan, sekarang tidak lagi dilakukan karena harus melalui rapat pleno BPD sehingga masing-masing kegiatan harus dicermati secara bersama-sama untuk diputuskan apakah sudah sesuai atau belum. Inilah yang pendamping katakan sebagai pelibatan secara substansi.

Tabel 1. Milestones Program Tata Kelola Keuangan Desa

\begin{tabular}{|c|c|c|}
\hline Program & Capaian & Produk \\
\hline $\begin{array}{c}\text { Tata Kelola } \\
\text { Keuangan Desa }\end{array}$ & $\begin{array}{l}\text { 1. Tersusunnya dokumen Perdes } \\
\text { PAPBDes tahun2016. } \\
\text { 2. Tersusunnya dokumen Perdes Laporan } \\
\text { Realisasi Pelaksanaan APBDes2016. } \\
\text { 3. Tersusunnya dokumen Perdes } \\
\text { RKP Tahunan tahun } 2017 . \\
\text { 4. Tersusunnya dokumen } \\
\text { RAPBDes tahun2017. } \\
\text { 5. Semua desa dampingan sudah } \\
\text { mampu melakukan penatausahaan } \\
\text { keuangan desa (seperti proses } \\
\text { pengajuan permintaan anggaran } \\
\text { (SPP), BKU, Buku Kas Pembantu } \\
\text { Kegiatan, Buku Bank, Buku Pembantu } \\
\text { Pajak, PTJB) secara mandiri. } \\
\text { 6. Perangkat desa mampu menyusun } \\
\text { laporan semester dan akhir tahun } \\
\text { secara mandiri (tidak njahitke). }\end{array}$ & $\begin{array}{ll}\text { 1. Perdes PAPBDes } & \\
& 2016 . \\
\text { 2. } & \text { Perdes Laporan } \\
& \text { Realisasi } \\
& \text { Pelaksanaan } \\
& \text { APBDes } 2016 . \\
\text { 3. Perdes RKP } \\
\text { Tahun 2017. } \\
\text { 4. Perdes APBDes } \\
\text { 2017. }\end{array}$ \\
\hline
\end{tabular}

\section{Peningkatan Kapasitas Badan Permusyawarahan Desa (BPD)}

Salah satu kunci kemandirian desa adalah terbangunnya sistem tata kelola pemerintahan desa yang baik. Dengan menguatnya peran desa melalui UU Desa, peranan sumua unsur lembaga desa, yaitu BPD dan LKD lainnya harus lebih ditingkatkan lagi. Wujud kesejahteraan masyarakat desa tidak lagi dipengaruhi oleh niat baik dari kepala desa semata, tetapi wujud kebersamaan yang harus dibangun bersama dengan lembaga desa yang lain untuk berupaya menjadikan masyarakat desa yang sejahtera dan mandiri. Tujuan utama peningkatan kapasitas BPD ini adalah dalam rangka membangun adanya keberimbangan kekuasaan di desa yang awalnya sangat sentralistik pada kepala desa bisa sedikit bergeser dengan adanya pengawasan dari lembaga desa yang lain karena ada sebuah istilah "Power tend to corrupt, but absolute power corrupt absolutely". Kegiatan yang dilakukan dalam rangka peningkatan kapasitas BPD adalah dengan melakukan pelatihan dan pendampingan kepada anggota BPD secara intensif selama 3 bulan secara berturut-turut. Desain kegiatan dilakukan melalui collaborative action, yang di 


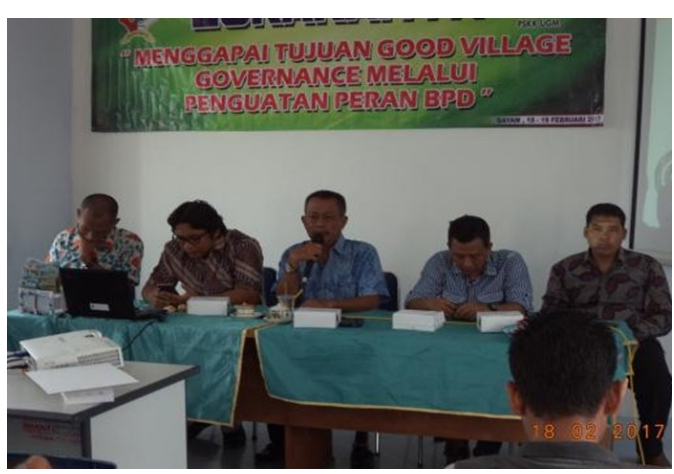

Gambar 5. Lokakarya "Menggapai Tujuan Good Village Governence melalui Penguatan BPD"

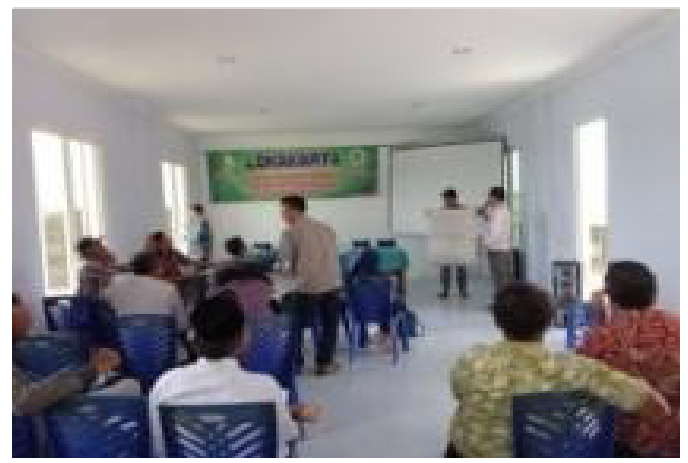

Gambar 6. Peserta Lokakarya Mempresentasikan Program Kerja BPD

dalamnya pemerintah kabupaten dan pemerhati desa yang lain dilibatkan dalam proses pelatihan dan pendampingan. Kegiatan pelatihan dan pendampingan yang dilakukan oleh tim melibatkan secara penuh partisipasi elemen pemerintah, baik kabupaten maupun kecamatan. Mereka bertindak sebagai narasumber, fasilitator, sekaligus peserta.

Peran BPD pada dasarnya adalah menjaga prinsip demokratisasi di desa. Besarnya kewenangan yang dimiliki oleh pemerintah desa harus diwadahi agar jalannya penyelenggaraan kewenangan tidak melanggar tata kelola pemerintahan yang baik. Peran BPD harus mengawal jalannya pemerintahan desa menuju desa yang lebih baik. Kewenangan yang luar biasa bagi pemerintah desa untuk mengatur semua aspek dalam lingkungan desa dan menguatnya kekuasaan yang ada di desa dibutuhkan pengawasan dan kontrol yang ketat oleh BPD.

Desa yang maju pada dasarnya sangat ditentukan oleh tiga hal. Pertama, kepala desa dan perangkat desa harus bersatu dengan masyarakat. Kedua, tata pemerintahan di desa haruslah demokratis. Ketiga, adanya partisipasi masyarakat dalam proses pembangunan yang ada di desa. Tujuan dari ketiga hal tersebut adalah untuk menghindari konflik kepentingan dan lebih memperhatikan kepentingan masyarakat secara keseluruhan, bukan pada golongan tertentu.

Peran BPD selain menjaga proses demokratisasi desa juga sebagai penyusunan perundang-undangan di desa. Ketentuan dalam PP 72 menyatakan bahwasanya setiap tahun, desa harus memiliki agenda program legislasi desa (Prolegdes). Produk perundang-undangan yang ada di desa salah satunya adalah Peraturan Desa (Perdes). Proses pengesahan Perdes harus mendapatkan persetujuan dari BPD. Persetujuan di sini berarti harus dilakukan pembahasan terlebih dahulu oleh BPD dalam bentuk rapat pleno. BPD yang ada di Gandu dan Madurejo serta BPD se-Kecamatan Gandu tidak pernah melakukan rapat pleno terlebih dahulu dalam memberikan persetujuan Perdes. Kendala yang muncul adalah BPD tidak mengetahui langkah apa yang harus dilakukan dalam melakukan tugas dan fungsinya. Lebih ironis lagi, dalam pemberian persetujuan Perdes, umumnya naskah Perdes diedarkan oleh perangkat desa ke rumah-rumah anggota BPD untuk meminta tanda tangan persetujuan dan berita acara pertemuan. Untuk itu, ke depannya, kasus-kasus seperti ini tidak boleh lagi terjadi.

Sampai akhir tahun 2017, dukungan terhadap pelaksanaan UU Desa di Kabupaten 


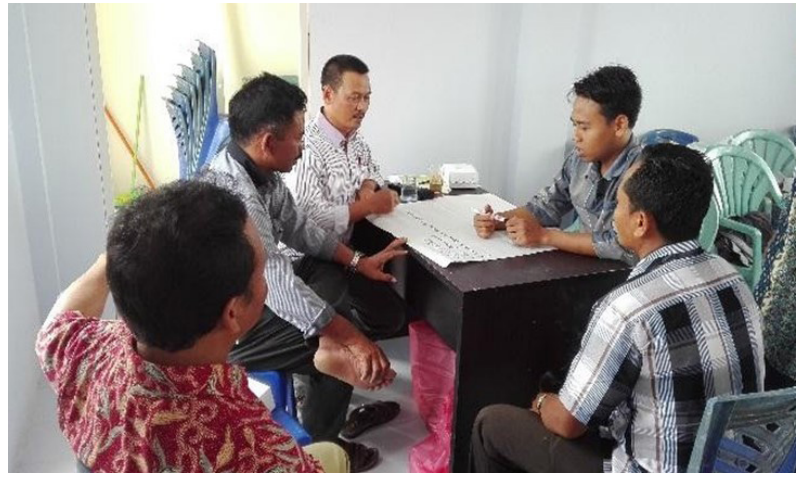

Gambar 7. Diskusi

Penyusunan Program BPD

Bojonegoro kurang berjalan justru dari pemerintah kabupaten sendiri. Perbup tentang Kewenangan Lokal Desa sebagaimana yang diamanatkan dalam Peraturan Pemerintah tentang pelaksanaan UU Desa belum ada. Justru yang dilakukan kabupaten semakin tidak jelas. Contohnya, pembangunan pasar di salah satu desa yang dibangun sendiri oleh desa memakai tanah desa justru malah digagalkan oleh kabupaten.

Di akhir paparannya, Camat juga menyampaikan bagaimana peranan BPD yang bertujuan mendukung pemerintahan desa. Pemateri yang kedua menyampaikan aspek teknis penyusunan produk-produk hukum yang ada di desa. Yang harus diperhatikan dalam menyusun produk hukum di desa adalah harus sesuai dengan kebutuhan yang ada di desa dan hanya mengikat masyarakat yang ada di desa tersebut. Peran BPD dalam penyusunan perundang-undangan di desa sangat vital. Agar proses pendampingan memiliki arah yang jelas, setiap desa diminta untuk melakukan kontrak kegiatan pendampingan sehingga di akhir kegiatan pendampingan ada nilai ukur yang jelas terkait dengan hasil pendampingan. Masing-masing desa diberikan waktu untuk melakukan diskusi terkait dengan kegiatan apa yang akan dicapai selama proses pendampingan. Setelah itu, masing-masing desa mempresentasikan hasilnya kepada semua peserta. Dengan adanya kontrak kegiatan ini, terjalinlah sebuah komitmen bersama antara pelaksana program dan penerima program terkait dengan apa yang harus dilakukan. Adapun hasil kontrak tersebut adalah sebagai berikut.

Tabel 2. Hasil Kontrak Kegiatan Pendampingan Peningkatan Kapasitas BPD

\begin{tabular}{|c|l|}
\hline Desa & \multicolumn{1}{|c|}{ Isi Kontrak/Komitmen } \\
\hline \multirow{4}{*}{ Gandu } & 1. Tersusunnya tata tertib BPD \\
& 2. Tersusunnya Keputusan BPD tentang Alat Kelengkapan BPD \\
& 3. Tersusunnya Program Kerja (Proker) BPD selama 1 tahun \\
& 4. Tersusunnya Prolegdes yang berasal dari usulan BPD \\
& 5. Tersusunnya dua draf Perdes yang berasal dari inisiatif BPD \\
& 1. Tersusunnya tata tertib BPD \\
& 2. Tersusunnya Keputusan BPD tentang Alat Kelengkapan BPD \\
& 3. Tersusunnya Program Kerja (Proker) BPD selama 1 tahun \\
& 4. Tersusunnya satu draf Perdes yang lahir dari inisiatif \\
& 5. BPD (Penataan Lembaga Kemasyarakatan Desa) \\
\hline
\end{tabular}


Berdasarkan kontrak kegiatan di atas, ternyata dalam pelaksanaannya, kegiatan pendampingan sangatlah membantu karena komitmen mereka sudah diikat terlebih dahulu di awal. Beberapa hasil dari pendampingan peningkatan kapasitas BPD yang langsung ditindak lanjuti adalah penyusunan tata tertib dan alat kelengkapan BPD. Penyusunan kedua dokumen tersebut penting untuk dilakukan, mengingat selama ini BPD tidak mengetahui Tupoksi dan mekanisme kerja yang dilakukannya. Untuk itu, tidak jarang muncul anggapan dari masyarakat bahwasanya BPD tidak berfungsi dan hanya "makan gaji buta".

Anggapan masyarakat tersebut bukanlah berlebihan jika kinerja BPD selama ini kurang bisa dirasakan manfaatnya oleh masyarakat. Atas kesadaran itulah, BPD di Desa Madurejo dan Gandu berkeinginan untuk membuktikan bahwasanya keberadaan mereka perlu ditunjukkan kepada masyarakat melalui kinerja nyata. Langkah yang dilakukan oleh anggota BPD adalah dengan menyusun Rencana Kerja Tahunan (RENJA) yang akan dijadikan pijakan mereka dalam melangkah. Proses dalam penyusunan program kerja ini tidaklah mudah, mengingat selama ini mereka tidak pernah melakukannya. Untuk itu, peran pendampingan sangatlah penting.

Penyusunan program kerja ini didasarkan pada alat kelengkapan yang sudah dibuat. Berdasarkan alat kelengkapannya, ada tiga komisi yang dibentuk, yaitu komisi bidang pemerintahan, komisi bidang pembangunan dan pemberdayaan masyarakat, serta komisi anggaran. Dari masing-masing komisi inilah dirumuskan program apa saja yang akan dibuat beserta implikasi biaya yang muncul dari masing-masing kegiatan tersebut. Peserta pendampingan cukup antusias mengikuti jalannya pendampingan kali ini. Hasil dari kegiatan ini adalah berupa dokumen rencana kerja BPD.

Pendampingan selanjutnya adalah penyusunan Perdes yang lahir dari inisiatif BPD. Berdasarkan kesepakatan yang dibuat diawal, untuk Desa Madurejo, ada satu Perdes yang akan dibuat oleh BPD, yaitu Perdes tentang Lembaga Kemasyarakatan Desa (LKD). Perdes tentang LKD ini penting untuk dirumuskan, mengingat selama ini peran dari LKD kurang maksimal. Sebagai contoh, peran RT dan RW di Desa Madurejo kurang berfungsi. Menurut Kepala Desa Madurejo, "RT dan RW kurang maksimal dalam bekerja, kita minta untuk melakukan pendataan saja tidak jalan, justru Dasa Wisma yang jalan”. Demikian juga dengan fungsi LKMD yang juga tidak berjalan. Untuk itu, perlu diatur secara jelas terkait dengan mekanisme penggantian, masa jabatan, serta kepengurusannya. Hasil dari pendampingan ini, selain dari keluarnya Perdes LKD, juga langsung ditindaklanjuti oleh pergantian beberapa RT dan pengurus LKD lainnya.

Pendampingan penyusunan Perdes di Desa Gandu yang berasal dari inisiatif BPD adalah penyusunan Perdes tentang BUMDes dan Perdes tentang Pengelolaan Keuangan dan Kekayaan Desa. Penyusunan kedua Perdes tersebut merupakan perdes yang saling terkait, mengingat panganggaran BUMDes yang akan dibuat harus jelas sumber pendanaannya. Untuk itu, perlu dibuatkan Perdes Pengelolaan Keuangan dan Kekayaan Desa. Pendampingan kedua perdes ini membutuhkan waktu cukup lama, yakni kurang lebih selama 2 bulan. Proses yang dilakukan oleh pendamping adalah menyiapkan seluruh sarana dan prasarana yang ada agar produk yang dihasilkan oleh perdes dan turunannya nanti bisa memenuhi aspirasi masyarakat dan BUMDes yang dihasilkan benar-benar berproses secara partisipatoris.

Proses pendampingan pendirian BUMDes diawali dengan penyusunan AD/ART 


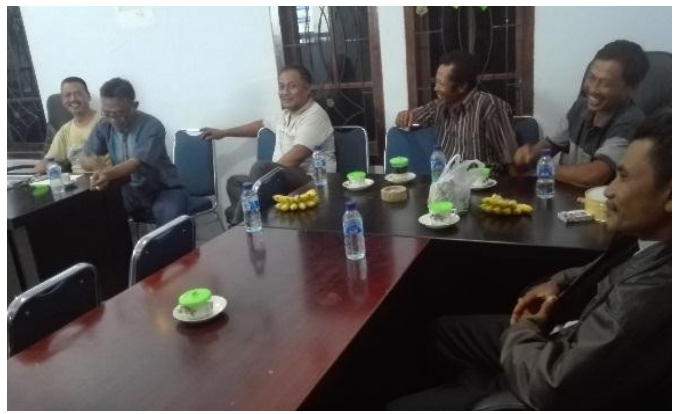

Gambar 9. FGD Para Anggota BPD

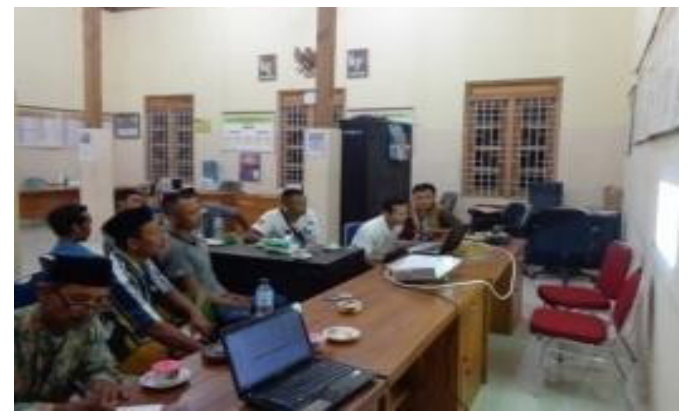

Gambar 8. Proses Pendampingan Penyusunan Program Kerja BPD

dan penentuan unit usaha apa yang sesuai dengan potensi wilayah yang ada di Desa Gandu. Dalam mempercepat pendirian BUMDes, pemerintah Desa Gandu membentuk panitia pendirian BUMDes. Penjaringan pengurus BUMDes dilakukan secara terbuka dengan persyaratan tertentu dan sesuai dengan kemampuan yang dimiliki oleh para calon.

Adapun hasil dari kepengurusan BUMDes Desa Gandu adalah (a) Sucipto (Direktur BUMDes); (b)Siti Mukhoiriyah (Menejer dministrasi dan keuangan BUMDes); (c) Sukandar (Menejer Operasional dan Logistik BUMDes); (d)Siswanto (manajer BUMDes). Kepengurusan yang sudah diputuskan untuk selanjutnya akan ditindaklanjuti dengan penerbitan SK oleh kepala desa agar segara diurus akta notaris.

Tabel 3. Milestones Program Peningkatan Kapasitas Badan Permusyawaratan Desa (BPD)

\begin{tabular}{|c|c|c|}
\hline Desa & Capaian & Produk \\
\hline Gandu & $\begin{array}{l}\text { 1. Anggota BPD mengetahui tugas } \\
\text { pokok dan fungsinya berdasarkan } \\
\text { ukuran kinerja yang sudah dibuat. } \\
\text { 2. Tersusunnya tata tertib BPD dan } \\
\text { alat kelengkapan BPD. } \\
\text { 3. Tersusunnya dokumen rencana kerja BPD. } \\
\text { 4. Tersusunnya satu Perdes berdasarkan } \\
\text { inisiatif BPD (Perdes tentang LKD). }\end{array}$ & $\begin{array}{l}\text { 1. Perdes LKD } \\
\text { 2. Tata Tertib } \\
\text { BPD }\end{array}$ \\
\hline Madurejo & $\begin{array}{l}\text { 1. Anggota BPD mengetahui tugaspokok } \\
\text { dan fungsinya berdasarkan } \\
\text { kinerja yang sudah dibuat. } \\
\text { 2. Tersusunnya tatib BPD dan } \\
\text { alat kelengkapan BPD. } \\
\text { 3. Tersusunnya dokumen rencana kerja BPD. } \\
\text { 4. Tersusunnya dua Perdes berdasarkan } \\
\text { inisiatif BPD. (Perdes tentang BUMDES } \\
\text { Pengelolaan Keuangan dan Kekayaan Desa). } \\
\text { 5. Terbentuknya BUMDes Desa Gandu. }\end{array}$ & $\begin{array}{l}\text { 1. Perdes } \\
\text { BUMDes } \\
\text { 2. Perdes } \\
\text { Pengelolaan } \\
\text { Keuangan } \\
\text { dan } \\
\text { Kekayaan } \\
\text { 3. Tatib BPD }\end{array}$ \\
\hline
\end{tabular}




\section{Refleksi Capaian Program}

Program Peningkatan Kapasitas Aparatur Pemerintahan Desa Tahun 2017 yang dilakukan oleh tim PSKK UGM telah berjalan dengan baik dan mampu meningkatkan pemahaman serta kapasitas aparat desa dan masyarakat sipil tentang tata kelola desa yang lebih memenuhi prinsip-prinsip tata pemerintahan yang baik. Kegiatan yang dijabarkan ke dalam beberapa tema kegiatan pelatihan dan pendampingan dinilai cukup efektif dalam meningkatkan kemampuan perangkat desa untuk mengelola pemerintahannya. Kegiatan tidak hanya memberikan panduan materi, tetapi juga mendampingi perangkat desa dan BPD dalam praktiknya, yang disesuaikan dengan kaidah perundang-undangan yang berlaku. Melalui kegiatan pendampingan, perangkat desa di Desa Gandu dan Madurejo tidak hanya memahami tupoksi, tetapi juga menjalankan tupoksi dan melaksanakan tugas dengan sebaik-baiknya.

Pada akhirnya, secara umum, program yang dilakukan oleh tim PSKK UGM ini mampu memberikan nilai-nilai positif dan beberapa best practise bagi perkembangan pemerintahan desa. Meskipun belum maksimal, dalam rentang waktu program 7 bulan sudah mulai nampak adanya perubahan di desa. Selain itu, mulai ditunjukkan pula perubahan positif dalam tata kelola keuangan desa, dari pengelolaan yang sangat tergantung kepada kecamatan dan konsultan untuk membuatkan laporan akhir hingga saat ini sudah mampu menyusun laporan keuangan desa secara mandiri.

Peningkatan kapasitas aparatur desa sudah diikuti oleh peningkatan kapasitas kelembagaan desa, terutama peran BPD sebagai salah satu lembaga kontrol terhadap pemerintah desa. BPD yang awalnya tidak terlihat kinerjanya kini sudah mampu menunjukkan perubahannya. Perubahan mendasar dari BPD adalah tersusunnya tatib dan alat kelengkapan BPD yang merupakan pijakan pokok bagi BPD dalam melakukan Tupoksinya. Selain itu, mulai ada kesadaran dari BPD bahwasanya peran BPD cukup strategis dalam pengambilan keputusan yang ada di desa sebagaimana yang diamanatkan dalam UU Desa.

\section{Penutup}

Berdasarkan berbagai hasil capaian kegiatan ini dan kondisi yang ditemui di lapangan, salah satu rekomendasi kebijakan yang diajukan adalah membentuk desa-desa percontohan atau desa model melalui program pendampingan lanjutan dengan memperluas desa dampingan. Apalagi dalam waktu dekat akan ada seleksi penerimaan perangkat desa baru yang mengalami kekosongan. Beberapa desa yang telah mengalami perubahan positif tersebut dapat menjadi role model dan bahan pembelajaran bagi sebagian desa lainnya, utamanya desa-desa yang perangkat desanya masih memerlukan lebih banyak motivasi dalam meningkatkan kapasitasnya untuk mendorong perbaikan dan kemajuan pemerintahan desa. Adapun beberapa rekomendasi usulan program ke depan berdasarkan capaian yang telah ada di antaranya adalah (i)penguatan BUMDes; (ii)pendampingan penyusunan dokumen tata ruang wilayah (mengingat pesatnya pembangunan yang dilakukan oleh desa); (iii)peningkatan kualitas pelayanan berbasis sistem aplikasi (smart villages). 


\section{Daftar Pustaka}

Agustina, E. (2019). "The Role of Community Empowerment Carried Out By Village Government in the Regional Autonomy Era" dalam UNIFIKASI: Jurnal Ilmu Hukum, 6(1), hlm. 34. doi: 10.25134/unifikasi.v6i1.1483.

Antlöv, H. (2003). "Village government and rural development in Indonesia: The new democratic framework" dalam Bulletin of Indonesian Economic Studies, 39(2), hlm. 193-214. doi: 10.1080/00074910302013.

Antlöv, H., A. Wetterberg, dan L. Dharmawan. (2016). "Village Governance, Community Life, and the 2014 Village Law in Indonesia" dalam Bulletin of Indonesian Economic Studies, 52(2), hlm. 161-183. doi: 10.1080/00074918.2015.1129047.

Phahlevy, R.R. (2016). "The Concept of Village Autonomy in Indonesia (Indonesian Constitution Perspective)" dalam Rechtsidee, 3(1), hlm. 27. doi: 10.21070/jihr. v3i1.151.

Syahidah, Q.A. (2018). Dana Desa Ditilap, Para Kades 'Tiarap'. Diakses dari rmol.id/ $\mathrm{read} / 2018 / 12 / 14 / 370748 /$ dana-desa-ditilap-para-kades-tiarap (Diakses pada 3 September 2020).

Vel, J.A.C. dan A.W. Bedner. (2015). "Decentralisation and village governance in Indonesia: The return to the nagari and the 2014 Village law" dalam Journal of Legal Pluralism and Unofficial Law, 47(3), hlm. 493-507. doi: 10.1080/07329113.2015.1109379.

Woodhouse, A. (2002). Village corruption in Indonesia: Fighting corruption in the World Bank's Kecamatan Development Program.

\section{Daftar Laman}

www.blokbojonegoro.com/read/article/20151214/pengisian-perangkat-desa-tungguperda.html

www.blokbojonegoro.com/read/article/20150401/tiap-desa-akan-butuh-1-tambahanperangkat.html

www.suarabojonegoro.com/2015/09/ujian-perangkat-desa-dilakukan-pemkab.html www.desamembangun.id/desa-harus-mampu-manfaatkan-celah-kecil-dalam-penerapanuu-desa

\section{Peraturan Perundangan}

Undang-Undang No. 6 Tahun 2014 tentang Desa

Peraturan Pemerintah No. 43 Tahun 2014 tentang Peraturan Pelaksanaan UndangUndang Nomor 6 Tahun 2014

Peraturan Pemerintah No. 47 Tahun 2015 tentang Perubahan Atas Peraturan Pemerintah Nomor 43 Tahun 2014 tentang Peraturan Pelaksanaan Undang-Undang Nomor 6 Tahun 2014 tentang Desa

Peraturan Menteri Desa, Pembangunan Daerah Tertinggal, dan Transmigrasi Republik Indonesia Nomor 1 Tahun 2015 tentang Pedoman Kewenangan Berdasarkan Hak Asal-Usul dan Kewenangan Lokal Berskala Desa

Peraturan Presinden Nomor 2 Tahun 2015 tentang Rencana Pembangunan Jangka Menengah Nasional (RPJMN) 2015-2019 